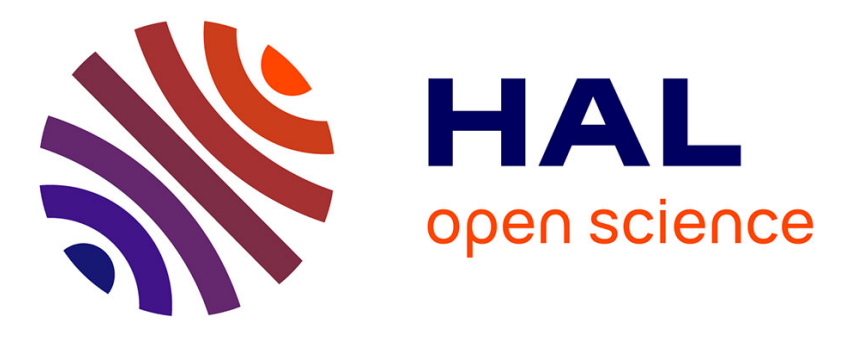

\title{
Ion exchange membranes based upon crosslinked sulfonated polyethersulfone for electrochemical applications
}

Walid Mabrouk, L. Ogier, Serge Vidal, Cyrille Sollogoub, F. Matoussi, J. F. Fauvarque

\section{To cite this version:}

Walid Mabrouk, L. Ogier, Serge Vidal, Cyrille Sollogoub, F. Matoussi, et al.. Ion exchange membranes based upon crosslinked sulfonated polyethersulfone for electrochemical applications. Journal of Membrane Science, 2013, 452, pp.263-270. 10.1016/j.memsci.2013.10.006 . hal-00980789

\section{HAL Id: hal-00980789 https://hal.science/hal-00980789}

Submitted on 30 Apr 2014

HAL is a multi-disciplinary open access archive for the deposit and dissemination of scientific research documents, whether they are published or not. The documents may come from teaching and research institutions in France or abroad, or from public or private research centers.
L'archive ouverte pluridisciplinaire HAL, est destinée au dépôt et à la diffusion de documents scientifiques de niveau recherche, publiés ou non, émanant des établissements d'enseignement et de recherche français ou étrangers, des laboratoires publics ou privés. 


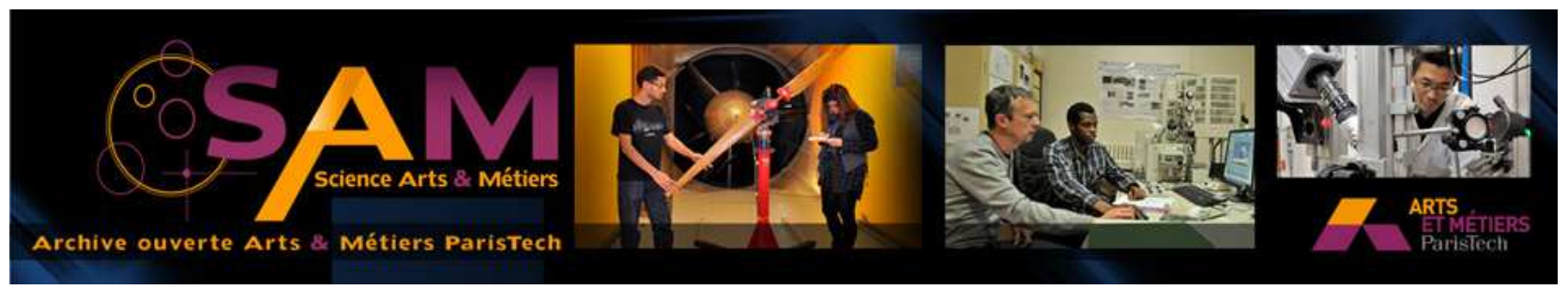

Science Arts \& Métiers (SAM)

is an open access repository that collects the work of Arts et Métiers ParisTech researchers and makes it freely available over the web where possible.

This is an author-deposited version published in: http://sam.ensam.eu Handle ID: .http://hdl.handle.net/10985/7995

\section{To cite this version :}

Walid MABROUK, Lionel OGIER, Serge VIDAL, Cyrille SOLLOGOUB, F. MATOUSSI - Ion exchange membranes based upon crosslinked sulfonated polyethersulfone for electrochemical applications - Journal of Membrane Science - Vol. 452, p.263-270 - 2013 


\title{
Ion exchange membranes based upon crosslinked sulfonated polyethersulfone for electrochemical applications
}

\author{
W. Mabrouk ${ }^{\mathrm{a}, \mathrm{b}, \mathrm{c}}$, L. Ogier ${ }^{\mathrm{a}}$, S. Vidal ${ }^{\mathrm{a}}$, C. Sollogoub ${ }^{\text {b,* }}$, F. Matoussi ${ }^{\mathrm{d}}$, J.F. Fauvarque ${ }^{\mathrm{b}}$ \\ a ERAS Labo, 222 RN 90, St Nazaire Les Eymes, 38330 Grenoble, France \\ b CNAM, P-2AM, EA4626, F75003 Paris, France \\ ' FST, Analytical Chemistry and Electrochemical Laboratory, Tunisie T1092, Tunisia \\ d INSAT, Chemical and Biological Engineering Department, Tunisie T1080, Tunisia
}

Keywords:

Ionic conductivity

Amino-polyethersulfone

Crosslinked sulfonated polyethersulfone

Proton exchange membrane fuel cell

\begin{abstract}
A B S T R A C T
Synthesis and characterization of new ion exchange membranes made from chlorosulfonated polyethersulfone $\left(\mathrm{SO}_{2} \mathrm{Cl}-\mathrm{PES}\right)$ crosslinked by polyaminated crosslinking reagents have been performed. Two examples are described: one crosslinked by hexane diamine, the other by amino-polyethersulfone $\left(\mathrm{NH}_{2}-\mathrm{PES}\right)$. Sulfonated polyether sulfone (S-PES) and $\mathrm{NH}_{2}$-PES have similar chemical structures that allow compatibility. Surprisingly enough, better results were obtained using amino-polyethersulfone. The best results have been obtained using $\mathrm{SO}_{2} \mathrm{Cl}$-PES with $1.3 \mathrm{SO}_{2} \mathrm{Cl}$ group per monomer unit crosslinked by 0.2 equivalent of $\mathrm{NH}_{2}$-PES. The membranes, less brittle than pristine SPES and insoluble in solvents such as DMAc, were characterized by TGA, DMA, DSC, ionic conductivity, transport numbers, and water swelling. The results showed that these membranes presented very promising performances for use in Proton Exchange Membrane Fuel Cells.
\end{abstract}

\section{Introduction}

Ion selective membranes are key components of many electrochemical processes, such as electrolysis, electrodialysis, fuel cells and many other processes. Nafion ${ }^{\circledR}$ is a cation conducting membrane, specially designed for brine electrolysis, producing chlorine and soda. Its perfluorinated backbone is resistant to oxidative attack by chlorine and to degradation by nucleophilic attack by hydroxyl anion. Super-acidic sulfonic acid pendant groups are responsible for a good cationic conductivity, in the range of 0.1$0.3 \mathrm{~S} / \mathrm{cm}$ for hydrated protons. Quite naturally, it was used in Proton Exchange Membrane Fuel Cells (PEMFC) as soon as "soluble" Nafion ${ }^{\circledR}$ was available for the preparation of the catalytic layers where electrochemical reactions occur [1]. Several other perfluorinated membranes have been designed for these uses (Flemion ${ }^{\circledR}[1]$, Aquivion ${ }^{\circledR}$ [2], etc.) with some advantages, like thermal stability, strong water retention and high proton conductivity. Nevertheless, the main drawback of those perfluorinated membranes is their high cost, fluorine and synthesis of sulfonated copolymers being very expensive [1]. If chemical resistance for degradation is unnecessary, cheaper membranes may be appropriate, such as those made from sulfonated polystyrene crosslinked by divinylbenzene [3]. Still, there is a need for mechanically

\footnotetext{
* Corresponding author. Tel.: +331402724 01; fax: +331402720 51 .

E-mail address: cyrille.sollogoub@cnam.fr (C. Sollogoub).
}

and chemically resistant ion conductive membranes that could be used in place of Nafion ${ }^{\circledR}$, for example in PEMFC.

"Hydrocarbon" proton conducting membranes have been designed as an alternative to perfluorinated membranes [4,5]. High performance polyarylenes are resistant to oxidation, thermostable and are mechanically strong with a relatively high glass transition temperature ( Tg). Polyarylene ether ketones (PEEK) [610] and polyarylene ether sulfone (PES) [11-20], commercially available, have been largely studied as polymeric backbones partially sulfonated on the main chain. The electron deficient parts of the polyarylenes may be sulfonated by metal-organic deprotonation, followed by reaction with sulfur electrophilic reagents. It is claimed that the resulting sulfonic acid functions are more stable than those obtained by direct electrophilic sulfonation. Direct electrophilic substitution is however easier to obtain and to control, and the resulting products have shown sufficient stability for fuel cell application.

Our work has been based on commercial polyether sulfone UDEL $^{\circledR}$ available from Solvay. Genova-Dimitrova et al. [12] have shown that it can be sulfonated with a degree of sulfonation easily controlled up to 1.3 sulfonic group per monomeric unit (pmu) and cast in proton conducting membranes from dimethyl acetamide (DMAc) solutions. The high $\mathrm{Tg}$ of these materials is responsible for the membrane brittleness, while a high sulfonation degree causes solubility in water at high temperature. As presented by Kreuer [4], SPES containing 1 sulfonic acid pmu becomes water soluble at $80{ }^{\circ} \mathrm{C}$, a behavior common to any sulfonated polyarylene. To overcome this problem, we proposed in a previous study [21] to 
substitute part of the sulfonic groups by aliphatic (n-octyl) sulfonamide groups (SPESOS). This operation led to an increased softness of the membrane as well as a sufficient ionic conductivity. Conductivity similar to that of the Nafion ${ }^{\circledR}$ membrane was found when blending SPESOS with a matrix of SPES [22].

Another promising approach to prevent any long term water solubilization is to crosslink the membranes [5]. Several methods are described in the literature for crosslinking polyarylene sulfonic acids. Nolte et al. [17] combined diamines to $\mathrm{SO}_{3} \mathrm{H}$ groups using carbodiimide as a dehydrating agent, forming sulfonamide bridges. The process is difficult and gives secondary products. Kerres et al. [23] developed another covalent crosslinking of polyether sulfone derivatives and the authors found that brittleness and water swelling of the obtained membranes were strongly diminished. Later, Kerres et al. [24] designed ionically crosslinking using polyaryl sulfonate and poly (het)aryl $\mathrm{N}$ base, by proton transfer from polyaryl sulfonic acid to the polymeric base. A polyether sulfone with allyl pendant chains was synthesized by Feng et al. [25]. Free radical crosslinking was performed by thermal decomposition of an initiator. Free radical crosslinking of polysulfone based polymer electrolyte membranes was also obtained by gamma ray irradiation [26]. $\mathrm{SO}_{2}$ bridges were obtained from sulfonated polyimides by treatment in a solution of phosphorous pentoxide in methane sulfonic acid [27]. The membranes were claimed to have good mechanical properties (high percentage of strain when stressed), low water swelling and good ionic conductivities [28]. Both covalent and ionic acid-base crosslinkings of poly(arylene ether sulfone) were achieved by introducing quinoxaline crosslinkages, after a multistep synthesis [29]. Crosslinking may also be based on physical interaction. Recently, Chen et al. [30] synthesized semi-crystalline hydrophobic poly(ether ketone)-hydrophilic disulfonated poly(arylene ether sulfone). Mikhailenko et al. [31,32] proposed a new cross-linking route using simple polyol molecules (ethylene glycol or glycerol) as crosslinking agents, and based on thermally activated interchain linkage. The obtained membranes were found to be stable in hot water and highly proton conductive. Nevertheless, it is clear that many of these crosslinking methods need sophisticated syntheses, and few of them have been tested in actual fuel cell experiment.

In this study, we used a very simple crosslinking method based on the availability of chlorosulfonated polyethersulfone $\left(\mathrm{SO}_{2} \mathrm{Cl}\right.$ $\mathrm{PES})$ with a tunable ratio of pendant $\mathrm{SO}_{2} \mathrm{Cl}$ pmu. This pendant group $\mathrm{SO}_{2} \mathrm{Cl}$ is very reactive and crosslinking may be easily obtained using a diamine or a polyamine. The non-reacted $\mathrm{SO}_{2} \mathrm{Cl}$ groups are transformed through hydrolysis into sulfonic acid groups $\left(\mathrm{SO}_{3} \mathrm{H}\right)$ that remain available for proton transfer. We used two different crosslinking agents (hexane dimanine and aminopolyether sulfone $\left(\mathrm{NH}_{2}\right.$-PES)) and synthesized then two new crosslinked proton exchange membranes. The crosslinked membranes have been characterized, both mechanically and electrochemically, and compared with uncrosslinked and commercial membranes. Finally, the fuel cell performances of the membranes have been investigated.

\section{Experimental}

\subsection{Materials}

Polyethersulfone (UDEL P-3500 ${ }^{\circledR}$ ) was obtained from Solvay Polymer. Chlorotrimethylsilane, palladium on activated charcoal, acetic anhydride, ammonium nitrate and chlorosulfonic acid were purchased from Aldrich. Petroleum ether, tetrahydrofurane, methanol, dichloromethane, dichloroethane were purchased from
VWR. Hydrochloric acid, sodium hydroxide, sodium bicarbonate and acetic acid were purchased from Laurylab. Dimethylacetamied, acetic anhydride, trifluoroacetic anhydride were purchased from Acros. Phosphorus pentachloride was purchased from Fluka. Nafion ${ }^{\circledR} 117$ membrane was supplied by DuPont. The thickness of Nafion ${ }^{\circledR} 117$ membrane in H-form was $175 \mu \mathrm{m}$ in dry state and $210 \mu \mathrm{m}$ in wet state.

\subsection{Synthesis of amino-polyethersulfone $\left(\mathrm{NH}_{2}\right.$-PES)}

The amino-polyethersulfone $\left(\mathrm{NH}_{2}\right.$-PES) was obtained by reduction of nitrated polyethersulfone $\left(\mathrm{NO}_{2}\right.$-PES). Amination of polysulfones by nitration and reduction has been widely reported in the literature [33-38]. Nitration of the PES was carried out in dichloromethane by adding small amounts of ammonium nitrate (AN), suspended in the PES solution. Acetic anhydride (AA) was added dropwise to this cold solution and for trapping water produced by the electrophilic substitution. Then sulfuric acid was added dropwise at $3{ }^{\circ} \mathrm{C}$, in order to trigger nitration of the PES. The reaction mixture was stirred for $12 \mathrm{~h}$ at $45^{\circ} \mathrm{C}$, under argon atmosphere before being precipitated in methanol and washed with a saturated solution of sodium bicarbonate $\left(\mathrm{NaHCO}_{3}\right) . \mathrm{NO}_{2}$-PES was washed by distilled water to neutralize the polymer $[33,36,38]$. Finally, it was dried under a vacuum at $80{ }^{\circ} \mathrm{C}$ for $6 \mathrm{~h}$.

$\mathrm{NH}_{2}$-PES can be obtained by reduction of $\mathrm{NO}_{2}$-PES. Hydrogenation was carried out in a solution using palladium deposited on activated charcoal as catalyst and tetrahydrofuran as solvent at $100{ }^{\circ} \mathrm{C}$ and 55 bars of hydrogen pressure, in presence of acetic acid. The reaction mixture was filtered and precipitated in an aqueous solution of sodium hydroxide $[39,40]$. The polymer was neutralized by washing with distilled water. $\mathrm{NH}_{2}$-PES was finally dried under vacuum at $80^{\circ} \mathrm{C}$ for $12 \mathrm{~h}$. Fig. 1 presents the different steps of the synthesis of $\mathrm{NH}_{2}$-PES.
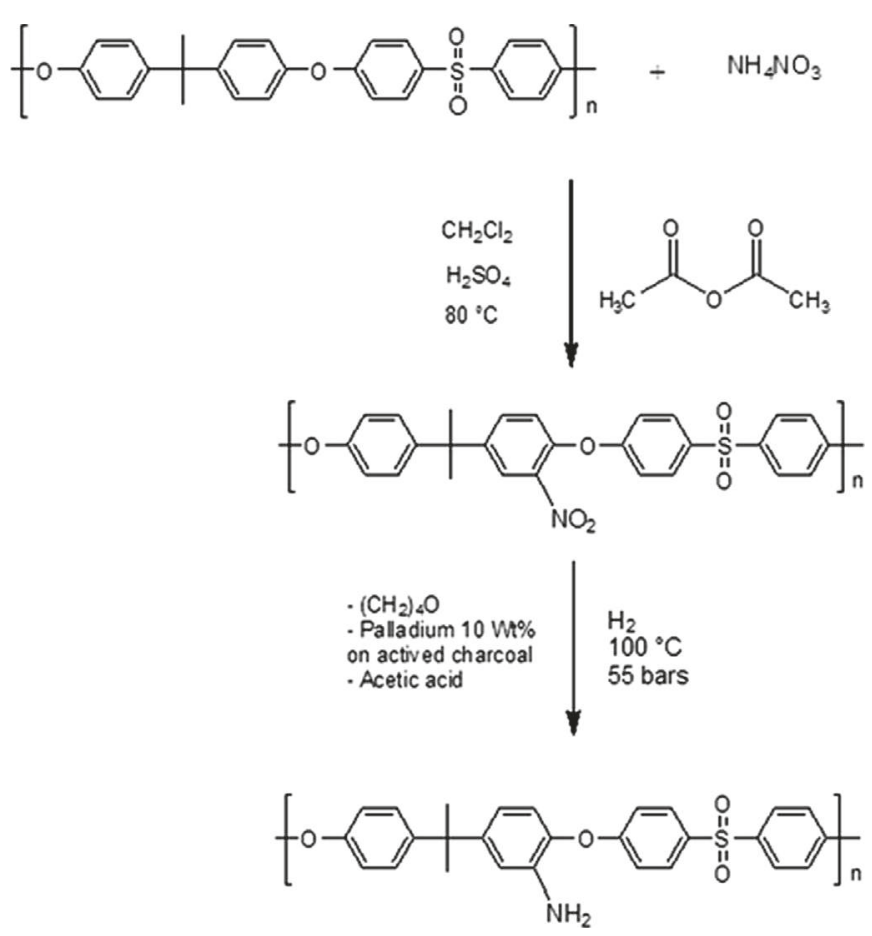

Fig. 1. Synthesis of $\mathrm{NH}_{2}$-PES. 


\subsection{Membrane preparation}

Two types of membrane were obtained from the crosslinking of the chlorosulfonated PES $\left(\mathrm{SO}_{2} \mathrm{Cl}-\mathrm{PES}\right)$. The chlorosulfonation of the PES has been reported previously. The crosslinking reagent was commercial hexane diamine to obtain the so-called $\mathrm{HEXCl}$ membrane and $\mathrm{NH}_{2}$-PES to get the so-called $\mathrm{ClNH}_{2}$ membrane. The membrane preparation was similar for the two membranes and as follows: the crosslinking agent and $\mathrm{SO}_{2} \mathrm{Cl}$-PES were dissolved separately at room temperature in dimetylacetamide (DMAc) at $10 \mathrm{wt} \%$, and mixed under cooling. The resulting viscous polymer solution was stirred during $15 \mathrm{~min}$ at low temperature (about $4{ }^{\circ} \mathrm{C}$ ) under argon bubbling to remove part of generated $\mathrm{HCl} .0 .2 \mathrm{~mol}$ equivalents of $\mathrm{NH}_{2}$-PES (or hexane diamine) was reacted with $\left(-\mathrm{SO}_{2} \mathrm{Cl}\right)$ groups of $\mathrm{SO}_{2} \mathrm{Cl}-\mathrm{PES}$. Then, the clear polymer solution was filtered through Nylon AG Sefar Nitex $60 \mu \mathrm{m}$. The recovered solid mass was negligible. The polymer solution was placed on a Teflon plate $\left(30 \times 15 \mathrm{~cm}^{2}\right)$. Drying and subsequent crosslinking were performed in an oven, at $40^{\circ} \mathrm{C}$ for $6 \mathrm{~h}$, then at $70^{\circ} \mathrm{C}$ for $6 \mathrm{~h}$ and finally at $100{ }^{\circ} \mathrm{C}$ for $12 \mathrm{~h}$. After cooling, the resulting membranes were peeled off from Teflon in the presence of distilled water. The remaining sulfochlorated groups were converted to sulfonated groups by hydrolysis. The thickness of dry membranes was about $120 \mu \mathrm{m}$. At low temperature, generated $\mathrm{HCl}$ is partly trapped by remaining $\mathrm{NH}_{2}$ groups, which are deactivated for crosslinking and the solution becomes viscous but is not gelled. When the reaction is conducted at higher temperatures, the solution is gelled and no membrane can be obtained. Fig. 2 presents the scheme of crosslinking of $\mathrm{ClNH}_{2}$ membranes. The crosslinking was confirmed by the insolubility of the membranes in the reaction solvent (DMAc).

\subsection{Characterization and measurements}

${ }^{1} \mathrm{H}$ NMR spectra were recorded on a Bruker AC200 spectrometer. FT-IR spectra were recorded on a Perkin Elmer Spectrum 100 series. Thermogravimetric Analysis (TGA) was performed using a Perkin Elmer TGA 6 in nitrogen (flow rate $=40 \mathrm{~mL} / \mathrm{min}$ ) at a heating rate of $7{ }^{\circ} \mathrm{C} / \mathrm{min}$. Differential Scanning Calorimetry (DSC) measurements were carried out with a TA Instrument. The
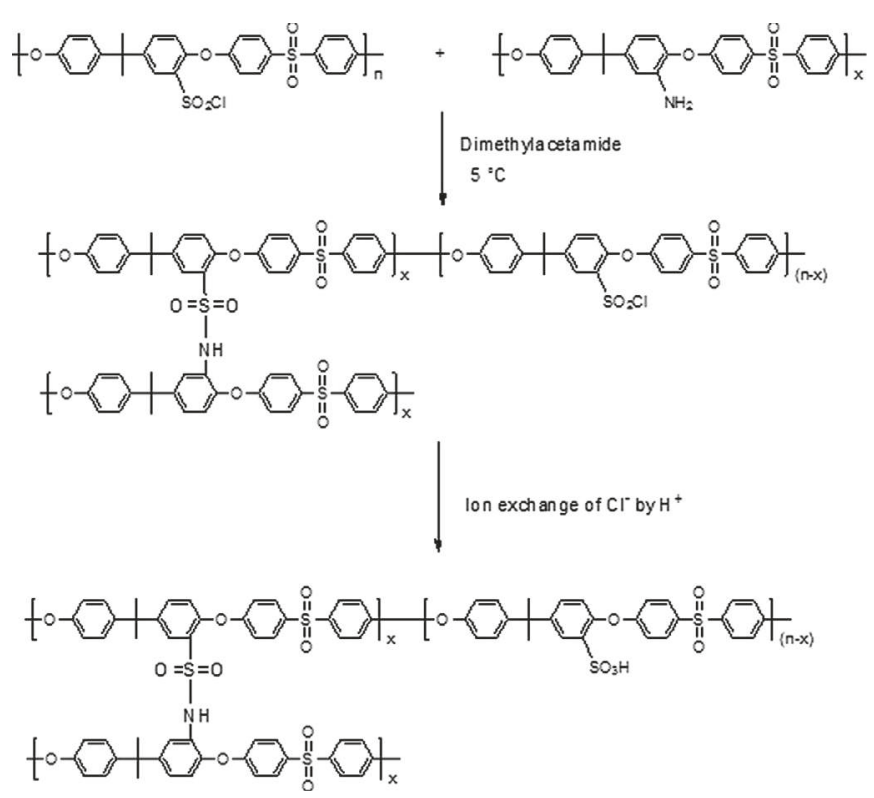

Fig. 2. Scheme of crosslinking of $\mathrm{ClNH}_{2}$ membranes. thermograms were registered between 20 and $300{ }^{\circ} \mathrm{C}$ with a sweep rate of $5{ }^{\circ} \mathrm{C} / \mathrm{min}$ under an argon flow of $40 \mathrm{~mL} / \mathrm{min}$. Dynamic Mechanical Thermal Analysis (DMTA) measurements were recorded using a TA Instruments DMA Q800 spectrometer in dry air (flow rate $=50 \mathrm{~mL} / \mathrm{min}$ ) at a heating rate of $3{ }^{\circ} \mathrm{C} / \mathrm{min}$. Tensile tests were performed using Instron tensile machine at $23{ }^{\circ} \mathrm{C}$ and $60 \%$ relative humidity at a crosshead speed of $2 \mathrm{~mm} / \mathrm{min}$. Membrane bars had a typical size of $25 \mathrm{~mm} \times 5 \mathrm{~mm}$ (test area) and a thickness of around $0.1 \mathrm{~mm}$. At least 4 measurements were done for each membrane.

Measurements of water absorption have been performed after drying the membranes at $100{ }^{\circ} \mathrm{C}$ under vacuum overnight. The membranes with area $3 \mathrm{~cm} \times 3 \mathrm{~cm}$ were soaked in ionized water at 25 and $80^{\circ} \mathrm{C}$, during 3 and $1 \mathrm{~h}$ respectively. The weight and the dimensional length gain were recorded. The water uptake was obtained by calculating the percentage of weight gain with respect to the dried membrane weight. The swelling ratio was obtained by calculating the percentage of length gain with respect to the dried membrane length.

The ionic conductivities of proton exchange membranes were measured at $25{ }^{\circ} \mathrm{C}$ using a conductimetric clamp in $1 \mathrm{M} \mathrm{H}_{2} \mathrm{SO}_{4}$. The resistances of membranes were measured with a Hameg Instrument Conductimeter, LC-meter HM 8018, as described in the paper of Chen et al. [41]. Ionic conductivity of the membrane, $\sigma(\mathrm{S} / \mathrm{cm})$, was determined owing to the following relation:

$$
\sigma=\frac{l}{R_{\text {membrane }} S}
$$

where $l$ is the membrane thickness $(\mathrm{cm}), S$ is the membrane surface exposed to the electric field $\left(0.785 \mathrm{~cm}^{2}\right)$, and $R_{\text {membrane }}$ is the membrane resistance $(\Omega)$.

Intrinsic conductivities at different temperatures and relative humidity have been measured using a Fumatech (MK3) apparatus. A four points probe was used on a sample $4 \times 0.8 \mathrm{~cm}^{2}$ of $\mathrm{ClNH}_{2}$ membrane. Equilibration of the membrane at different relative humidities required several hours.

The ion exchange capacity (IEC) has been determined by titration. A sample membrane in proton form was soaked for 2 days in $100 \mathrm{~mL}$ of an aqueous solution $10^{-2} \mathrm{NaOH}$ and the released proton was titrated with a $10^{-3} \mathrm{M} \mathrm{H}_{2} \mathrm{SO}_{4}$ solution [42]. The ion exchange capacity was determined from the following relation:

$I E C=\frac{\left(n_{\mathrm{NaOH}}^{i}-n_{\mathrm{NaOH}}^{f}\right)}{W_{d r y}}$

The cationic transport number was measured using a Hittorf Cell: the cell is constituted of two symmetrical glass compartments, each one was filled with aqueous $\mathrm{H}_{2} \mathrm{SO}_{4} 1 \mathrm{M} 50 \mathrm{~mL}$. The membrane is motionlessly placed between them, separated by two compartments full of the same $\mathrm{H}_{2} \mathrm{SO}_{4}$ solution as described in previous papers $[43,44]$.

The proton exchange membrane was pre-treated before the fuel cell test: it was immersed in distilled water for $12 \mathrm{~h}$. A Membrane Electrode Assembly (MEA) was created using Paxitech ${ }^{\circledR}$ electrodes containing 5\% Nafion ${ }^{\circledR}$. The $25 \mathrm{~cm}^{2}$ or $64 \mathrm{~cm}^{2}$ membrane was sandwiched between a hydrogen electrode and an oxygen electrode that have a platinum loading of $0.5 \mathrm{mg} \mathrm{Pt} / \mathrm{cm}^{2}$. Thus, the active surfaces of the electrodes were wet with pure water. A drop of acidic silica gel was spread on the active layer of the two electrodes as an interfacial binder. The fuel cell performances were recorded at room temperature and under atmospheric pressure $\left(\mathrm{P}\left(\mathrm{H}_{2}\right)\right.$ and $\mathrm{P}\left(\mathrm{O}_{2}\right)$ equal to $1 \mathrm{~atm})$, using a Voltalab ${ }^{\circledR} \mathrm{PGZ301}$ potentiostat galvanostat the first time and with a current generator for current intensities higher than $1 \mathrm{~A}$. 


\section{Results and discussion}

\subsection{Polymer characteristics}

The chemical structure of the synthesized $\mathrm{NO}_{2}$-PES and $\mathrm{NH}_{2}-$ PES was identified by ${ }^{1} \mathrm{H}$ NMR and IR spectra. Fig. 3 shows the ${ }^{1} \mathrm{H}$ NMR spectra of $\mathrm{NO}_{2}$-PES and $\mathrm{NH}_{2}$-PES. $\mathrm{NO}_{2}$-PES reacted with hydrogen to reduce $-\mathrm{NO}_{2}$ functions. The polymers were obtained in quantitative yields. The different syntheses were repeatable and the conversion rate achieved $100 \%$. The reduction of $\mathrm{NO}_{2}$-PES can be followed by the progressive appearance of a new signal at $3.5 \mathrm{ppm}$ ( 2 protons by integration).

Fig. 4 shows the IR spectra of the PES, $\mathrm{NO}_{2}$-PES and $\mathrm{NH}_{2}$-PES that appear to be quite similar. In the IR study, the aromatic carbons can be observed as two absorption bands around 1470 and $1493 \mathrm{~cm}^{-1}$, the methyl groups of the different polymers appear with an intense band around $1345 \mathrm{~cm}^{-1}$. The $\mathrm{C}-\mathrm{O}-\mathrm{C}$ appears around $1150 \mathrm{~cm}^{-1}$. We observe on the spectrum of $\mathrm{NO}_{2}$-PES the appearance of an intense band around $1535 \mathrm{~cm}^{-1}$, assigned to the vibration of $\mathrm{N}=\mathrm{O}$. The reduction of $\mathrm{NO}_{2}$-PES can be followed by the disappearance of this band at $1535 \mathrm{~cm}^{-1}$ and the appearance
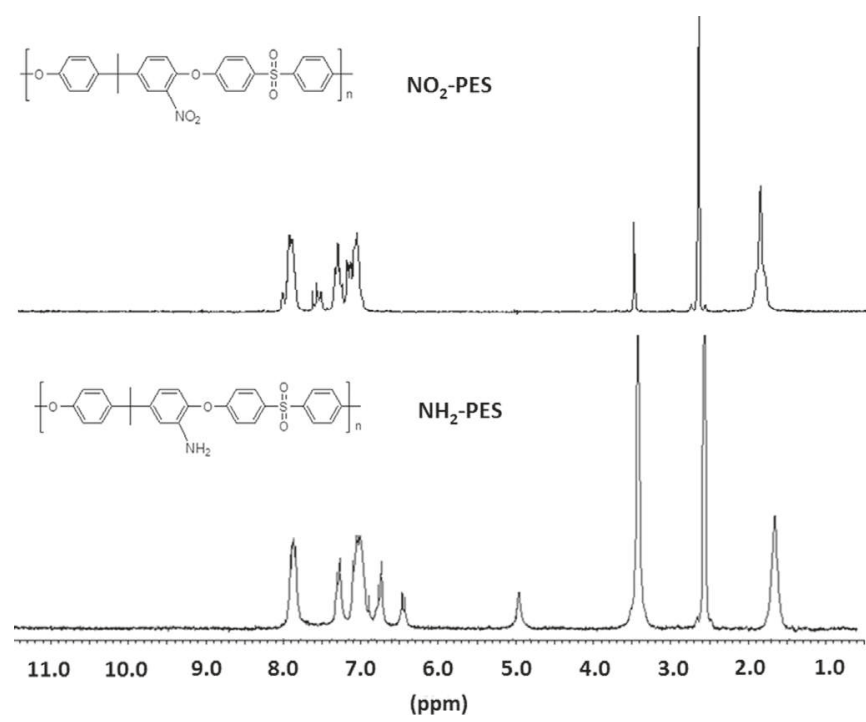

Fig. 3. ${ }^{1} \mathrm{H}$ NMR spectra of $\mathrm{NO}_{2}$-PES and $\mathrm{NH}_{2}$-PES. of two new bands at 3380 and $3480 \mathrm{~cm}^{-1}$ attributed to amino groups. IR-measurements on a sample taken after $2 \mathrm{~h}$ of hydrogenation show that nitro groups are still present, whereas, after $6 \mathrm{~h}$, the absorption band at $1535 \mathrm{~cm}^{-1}$ is not visible.

\subsection{Thermal characteristics}

The thermal stability of the membranes was investigated by TGA. Fig. 5 shows that both $\mathrm{ClNH}_{2}$ and $\mathrm{HEXCl}$ membranes present a very similar behavior and are stable in the temperature range between ambient and approximately $250{ }^{\circ} \mathrm{C}$. Both $\mathrm{ClNH}_{2}$ and $\mathrm{HEXCl}$ membranes exhibit two steps of weight loss. The first weight loss at around $100{ }^{\circ} \mathrm{C}$ is related to the adsorption of water bonded to the sulfonic groups. The second weight loss is attributed to the degradation of the sulfonic groups that starts for both membranes at $275^{\circ} \mathrm{C}$. In comparison, the degradation of Nafion ${ }^{\circledR}$ sulfonic groups starts at $325^{\circ} \mathrm{C}$. Nevertheless, the thermal stability of all the membranes is similar in the range temperature of the fuel cell application.

Differential Scanning Calorimetry (DSC) was used to characterize the thermal transition temperatures for the different membranes (PES, $\mathrm{NO}_{2}$-PES and $\mathrm{NH}_{2}$-PES, $\mathrm{ClNH}_{2}$ and $\mathrm{HEXCl}$ membranes). Fig. 6 shows the thermograms where the glass transition temperature $(\mathrm{Tg})$ of the commercial PES appears at $187^{\circ} \mathrm{C}$. For the other samples, the $\mathrm{Tg}$ is shifted to higher temperatures, indicating that nitration, hydrogenation and crosslinking increase the $\mathrm{Tg}$ of the PES.

$\mathrm{HEXCl}$ and $\mathrm{ClNH}_{2}$ membranes show a single glass transition temperature $(\mathrm{Tg})$ of 219 and $222{ }^{\circ} \mathrm{C}$ respectively, which proves that there is a miscibility between $\mathrm{SO}_{2} \mathrm{Cl}$-PES or hexamethylene diamine and $\mathrm{NH}_{2}$-PES.

\subsection{Water uptake and swelling}

The results of the water uptake and swelling ratio at 25 and $80{ }^{\circ} \mathrm{C}$ are given in Table 1 . The hydration of the membrane is closely related to its conductivity and the mechanical stability. The water uptake at $25{ }^{\circ} \mathrm{C}$ of $\mathrm{ClNH}_{2}$ and $\mathrm{HEXCl}$ membranes are $40 \%$ and $50 \%$, respectively. In comparison, the water uptake at $25{ }^{\circ} \mathrm{C}$ of the S-PES membrane $(1 \mathrm{H}+\mathrm{pmu})$ is equal to $118 \%$. This result proves that the chemical crosslinking decreases the hydrophilic character of the membranes and prevents from the polymer dissolution in

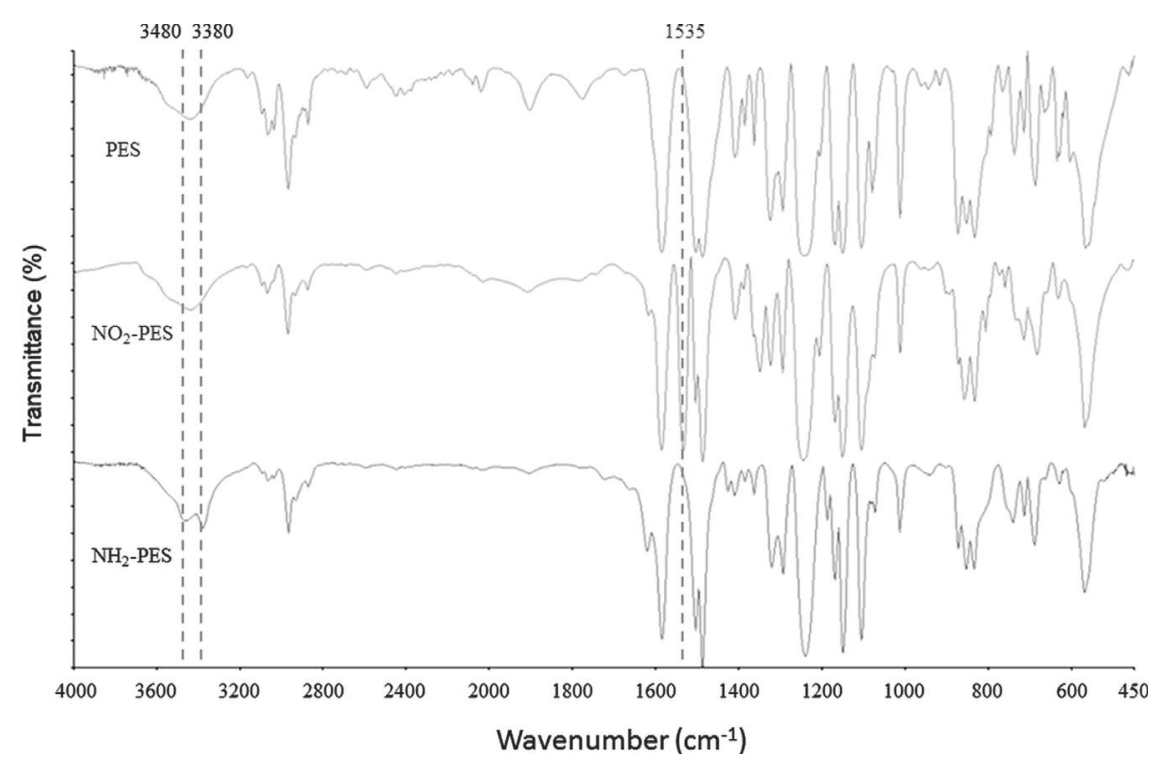

Fig. 4. IR spectra of synthesized polymers. 
water. We also observe that the swelling of both membranes at $25{ }^{\circ} \mathrm{C}$ is not excessive and allows maintaining adequate mechanical properties. We notice in particular that the water absorption behavior at $25{ }^{\circ} \mathrm{C}$ of $\mathrm{ClNH}_{2}$ is better than $\mathrm{HEXCl}$ and not so different from the Nafion ${ }^{\circledR}$, considering the slight difference in sulfonation rate between the two membranes.

At $80^{\circ} \mathrm{C}$, if the swelling is much more important, the membranes are still not soluble in water, contrary to the noncrosslinked membrane.

\subsection{Ionic conductivity}

Ionic conductivity of both $\mathrm{ClNH}_{2}$ and $\mathrm{HEXCl}$ is similar to that of Nafion ${ }^{\circledR}$ in $\mathrm{H}_{2} \mathrm{SO}_{4}$ solution $1 \mathrm{M}$ (Table 1 ). Two kinds of ionic conduction must be considered in the measurements. The first one was relative to the experimentation achieved by electrochemical impedance. It concerns the intrinsic ionic conduction of the membrane by the $\mathrm{H}^{+}$ions which were counter-ions, directly associated to negative ionic sites of the membrane. The second kind of concentration implies $\mathrm{H}^{+}$ions present in the sulfuric acid phase, absorbed by the membrane. A model of ionic concentration

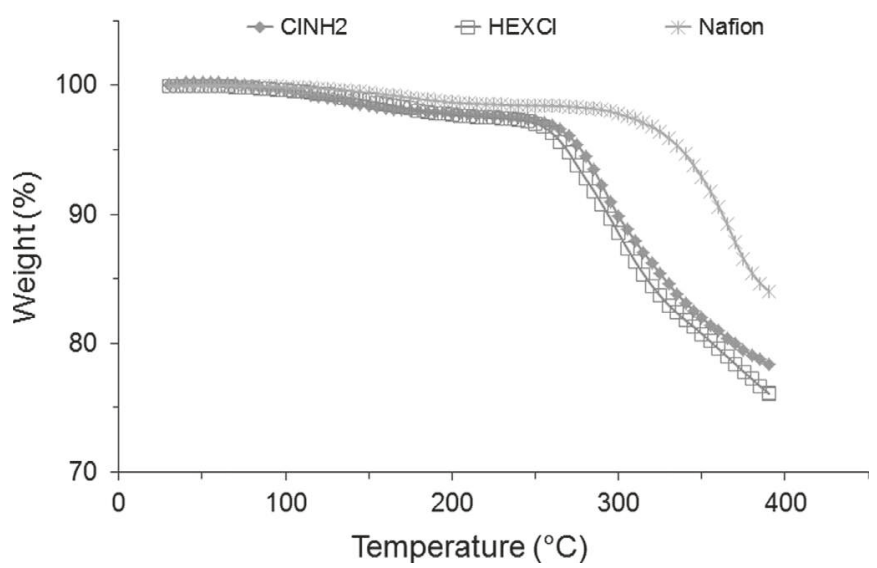

Fig. 5. TGA curves of the membranes.

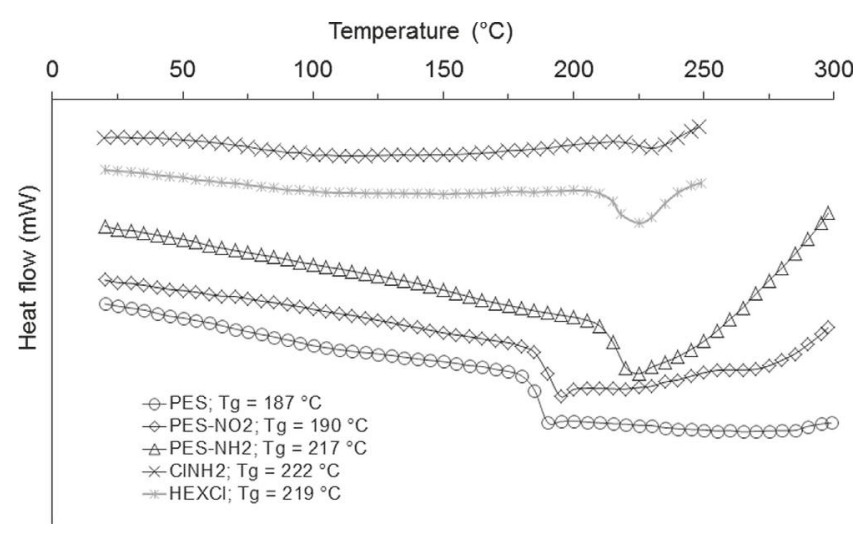

Fig. 6. DSC curves of the membranes. taking into account these two kinds of ionic concentration was already proposed by Zabolotsky et al. [45] and Zabolotsky and Nikonenko [46]. It was recently used by Gavach and coworkers to give an account of this phenomenon [47].

Intrinsic conductivities of $\mathrm{ClNH}_{2}$ membranes are lower than those reported for Nafion ${ }^{\circledR}$. Fig. 7 shows the relative humidity dependence of the proton conductivities for $\mathrm{ClNH}_{2}$ membranes at different temperatures. At $80^{\circ} \mathrm{C}, 95 \% \mathrm{RH}$, the measured intrinsic conductivity is ten times lower than that deduced from the fuel cell operation. Conversely, the conductivity at $100{ }^{\circ} \mathrm{C}, 95 \% \mathrm{RH}$ is anomalously high, maybe due to a large swelling. More experiments are necessary to confirm these tendencies, using particular membranes with different crosslinking rates.

Protonic transport numbers measured under a potential gradient are reported in Table 2. They were measured for the three membranes $\left(\mathrm{ClNH}_{2}, \mathrm{HEXCl}\right.$ and Nafion $\left.{ }^{\circledR}\right)$ as a function of the current density and the $\mathrm{H}_{2} \mathrm{SO}_{4}$ solution concentration. All the values measured by Hittorf's method were in the range of 0.99-1. These protonic transport numbers obtained for $\mathrm{ClNH}_{2}$ membranes are similar to those obtained with Nafion ${ }^{\circledR}$ membrane.

\subsection{Ion exchange capacity}

The ion exchange capacity (IEC) value of the membranes (in $\mathrm{H}^{+}$ form) is reported in Table 1. The value of IEC for the two membranes is in the range of $1 \mathrm{meq} / \mathrm{g}$ and is similar to the Nafion ${ }^{\circledR}$ commercial membrane.

The IEC of the membranes was evaluated by a volumetric titration and ${ }^{1} \mathrm{H}$ NMR, i.e. the difference in molar equivalent between amino groups reacted with sulfochlorated groups. The obtained results of IEC measured by ${ }^{1} \mathrm{H}$ NMR and volumetric titration are similar. These results prove that the amount of reactive amino groups is 0.2 equivalent per mole. This value was calculated theoretically and mentioned in the experimental section.

\subsection{Mechanical properties}

Fig. 8 shows the tensile stress-strain curves of the crosslinked membranes. All the membranes exhibit the same Young's modulus, around $1 \mathrm{GPa}$. It appears that $\mathrm{ClNH}_{2}$ membranes have a tensile strength (around $55 \mathrm{MPa}$ ) twice as high as the $\mathrm{HEXCl}$ membranes (around 25-30 MPa) as well as a much higher elongation at break (16\% for the $\mathrm{ClNH}_{2}$ compared to $5 \%$ for the $\mathrm{HEXCl})$. This indicates in particular that these membranes can undergo the stress of electrode attachment, when used in PEM applications, and are ductile enough even in the dry state.

DMTA curves, given in Fig. 9, show that the storage modulus of the two membranes remains constant from $20^{\circ} \mathrm{C}$ to around $200-$ $220^{\circ} \mathrm{C}$. At that temperature, a drop of the modulus occurs, associated with the glass transition temperature of the polymers. The values of the $\mathrm{Tg}$ obtained by DMTA are in accordance with those measured by DSC. As can be seen in Fig. 9, the Nafion exhibits quite similar thermomechanical behavior.

Table 1

Water uptake and ion exchange capacity of $\mathrm{ClNH}_{2}, \mathrm{HEXCl}$ and Nafion ${ }^{\mathbb{B}} 117$ membranes.

\begin{tabular}{|c|c|c|c|c|c|c|c|}
\hline & $\begin{array}{l}\text { Sulfonation rate } \\
\left(\mathrm{H}^{+} \mathrm{pmu}\right)\end{array}$ & $\begin{array}{l}\text { Water uptake at } 25^{\circ} \mathrm{C} \\
\text { (wt\%) }\end{array}$ & $\begin{array}{l}\text { Water uptake at } 80^{\circ} \mathrm{C} \\
\text { (wt\%) }\end{array}$ & $\begin{array}{l}\text { Swelling in water at } 25^{\circ} \mathrm{C} \\
\text { (\%) }\end{array}$ & $\begin{array}{l}\text { Swelling in water at } 80^{\circ} \mathrm{C} \\
\text { (\%) }\end{array}$ & $\begin{array}{l}\text { IEC } \\
\text { (meq/ } \\
\text { g) }\end{array}$ & $\begin{array}{l}\text { Conductivity } \\
(\mathrm{S} / \mathrm{cm})\end{array}$ \\
\hline $\mathrm{ClNH} 2$ & 1.1 & 40 & 76 & 3 & 33 & 1.5 & 0.1 \\
\hline $\mathrm{HEXCl}$ & 1.1 & 50 & 65 & 10 & 30 & 1.7 & 0.1 \\
\hline Nafion $^{(\mathbb{R})} 117$ & 0.9 & 35 & 47 & 7 & 27 & 1.2 & 0.1 \\
\hline
\end{tabular}




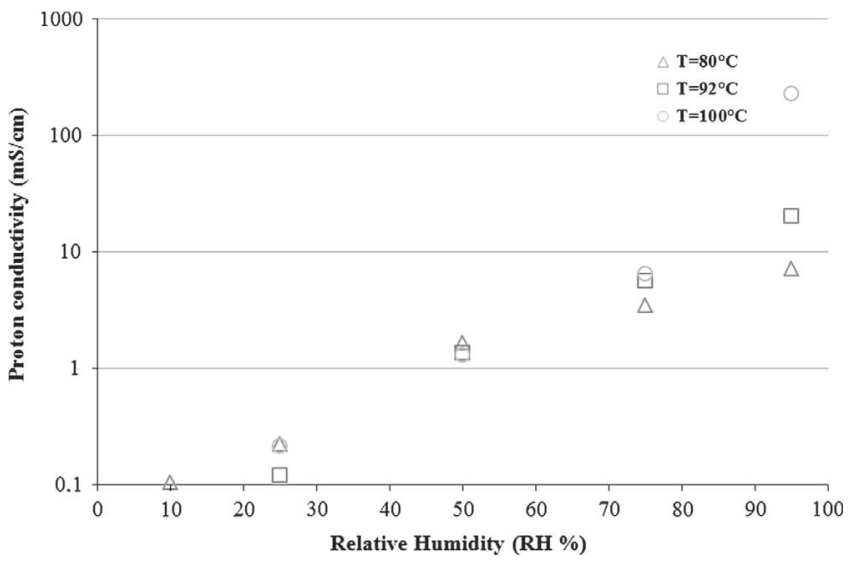

Fig. 7. Relative humidity dependence of the proton conductivity for different temperatures.

Table 2

Transport numbers of $\mathrm{ClNH}_{2}$ and $\mathrm{HEXCl}$ membranes.

\begin{tabular}{llllll}
$\begin{array}{l}\text { Surface } \\
\left(\mathrm{cm}^{2}\right)\end{array}$ & $\begin{array}{l}{\left[\mathrm{H} \mathrm{SO}_{4}\right]} \\
(\mathrm{M})\end{array}$ & $\begin{array}{l}\text { Current } \\
\text { intensity } \\
(\mathrm{mA})\end{array}$ & $\begin{array}{l}\text { Time } \\
(\mathrm{mn})\end{array}$ & $\begin{array}{l}t^{+} \\
\text {Cathodic }\end{array}$ & $\begin{array}{l}t^{+} \\
\text {Anodic }\end{array}$ \\
\hline 4.15 & 1 & 100 & 188 & 1.00 & 1.00 \\
4.15 & 1 & 70 & 243 & 1.01 & 1.01 \\
4.15 & 1 & 40 & 430 & 1.00 & 0.99 \\
4.15 & 1 & 100 & 188 & 1.01 & 1.00 \\
4.15 & 1 & 70 & 243 & 0.99 & 1.00 \\
4.15 & 1 & 40 & 430 & 0.99 & 0.99 \\
4.15 & 1 & 100 & 188 & 0.99 & 1.00 \\
4.15 & 1 & 70 & 243 & 1.00 & 1.00 \\
4.15 & 1 & 40 & 430 & 0.99 & 0.99 \\
& & & & &
\end{tabular}

\subsection{Fuel cell performances}

Performances in PEMFC for the different membranes are reported in Fig. 10. The open circuit potential in open circuit with the different membrane electrode assemblies (MEA) was in the range of 0.95 and $1 \mathrm{~V}$, similar to that obtained with a Nafion ${ }^{\mathbb{R}}$ membrane in similar conditions. We can notice that the electrochemical performances of $\mathrm{ClNH}_{2}$ and $\mathrm{HEXCl}$ membranes are superior to that of the Nafion ${ }^{\circledR} 117$ membrane using Paxitech ${ }^{\circledR}$ PEMFC cell $\left(64 \mathrm{~cm}^{2}\right)$.

The power density obtained at room temperature from the MEA with $\mathrm{ClNH}_{2}$ membrane was $180 \mathrm{~mW} / \mathrm{cm}^{2}$ at $430 \mathrm{~mA} / \mathrm{cm}^{2}$. They are also twice as high as the MEA with the Nafion ${ }^{\mathbb{R}}$ assembly which has a power density around $126 \mathrm{~mW} / \mathrm{cm}^{2}$ at $281 \mathrm{~mA} / \mathrm{cm}^{2}$. This difference can be attributed to interface electrode membrane.

It is worthy to notice that the current density measured for the Nafion is lower than the value usually found in the literature (see for example [48]). This is mainly due to the fact that in our study, a Nafion ${ }^{\circledR} 117$ membrane is used, in order to get thickness value similar to our membranes. In the literature, Nafion 112 or 115 is used, presenting lower thicknesses and consequently higher current density. Besides, the contact between electrode and membrane in our MEA still needs to be optimized.

Figs. 11 and 12 show the PEMFC performances of $\mathrm{ClNH}_{2}$ and Nafion ${ }^{\circledR} 117$ membranes performed at different cell temperatures. Open circuit voltage was in the range of $0.97-1 \mathrm{~V}$ for each assembly. The polarization curve at $100{ }^{\circ} \mathrm{C}$ is located at a lower level than the one at $80^{\circ} \mathrm{C}$ for the two MEA with $\mathrm{ClNH}_{2}$ and the Nafion ${ }^{\circledR}$ membranes. This limitation is probably due to inadequate

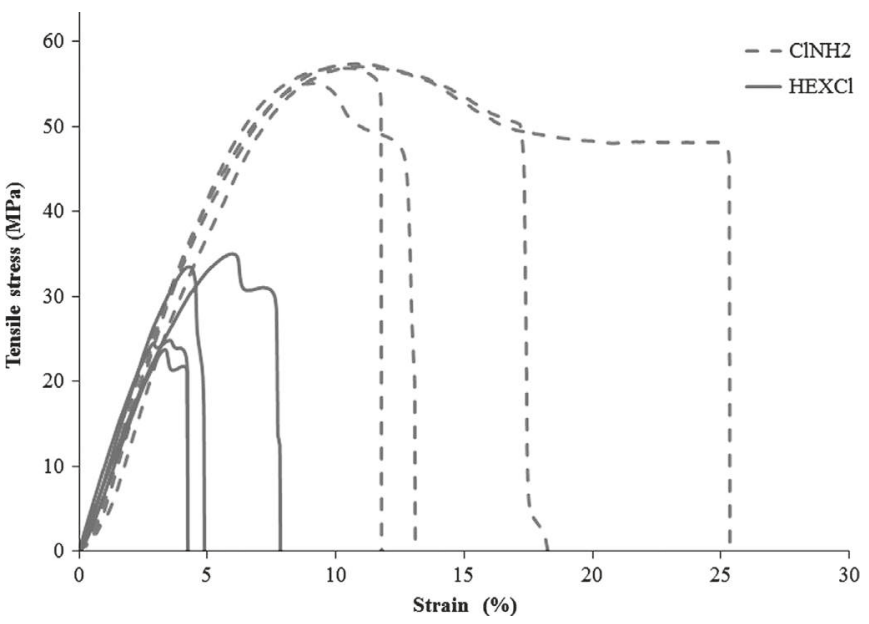

Fig. 8. Tensile stress-strain curves of the $\mathrm{HEXCl}$ and $\mathrm{ClNH}_{2}$ membranes.

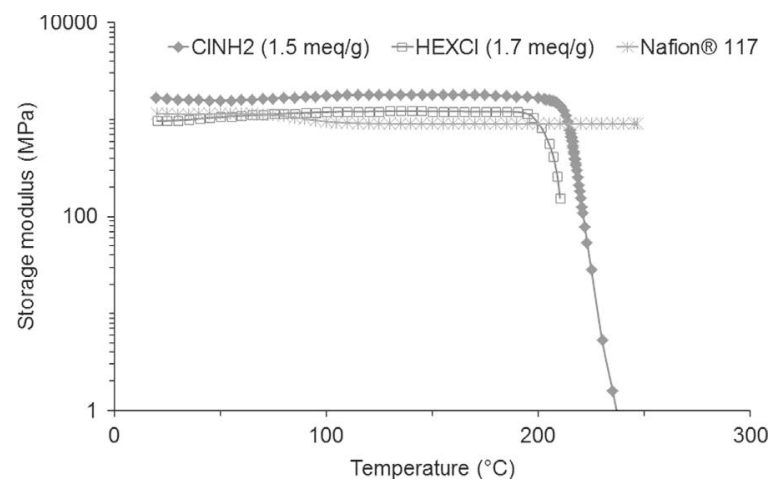

Fig. 9. DMTA curves of the membranes.

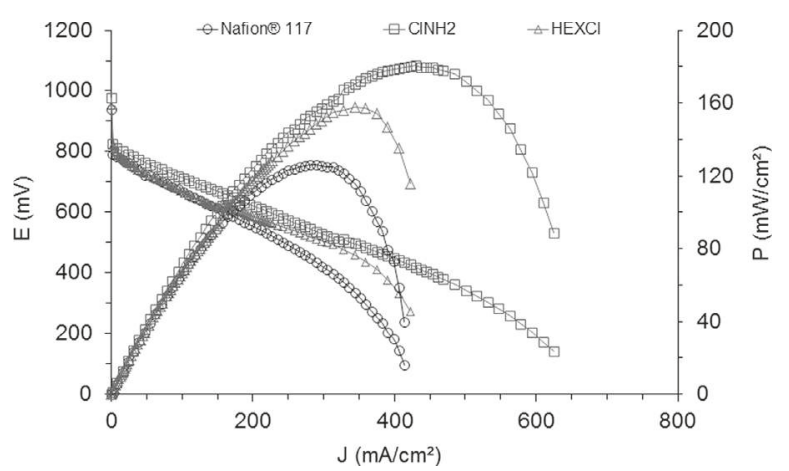

Fig. 10. Polarization curves of PEMFC PAXITECH, surface $=64 \mathrm{~cm}^{2}, \mathrm{H}_{2}$ and $\mathrm{O}_{2}$ flow rates $=321$ and $517 \mathrm{~cm}^{3} / \mathrm{min}$

hydration of the membranes caused by water evaporation at $100{ }^{\circ} \mathrm{C}$ in fuel cells. Nevertheless, the MEAs worked properly at high temperatures. At $80{ }^{\circ} \mathrm{C}$, the power density of the $\mathrm{ClNH}_{2}$ $\left(115 \mathrm{~mW} / \mathrm{cm}^{2}\right.$ at $\left.288 \mathrm{~mA} / \mathrm{cm}^{2}\right)$ is higher than the Nafion 117 $\left(98 \mathrm{~mW} / \mathrm{cm}^{2}\right.$ at $\left.196 \mathrm{~mA} / \mathrm{cm}^{2}\right)$.

An explanation for the good results in fuel cells obtained with crosslinked membranes could be that crosslinking allows keeping a kind of disorder favorable to conduction of solvated protons. More open structures with larger ion conducting channels are maybe obtained during crosslinking with $\mathrm{NH}_{2}$-PES that has a more rigid backbone than hexane diamine. Still investigations of the membrane structure at the nanoscale are needed to confirm this hypothesis. 


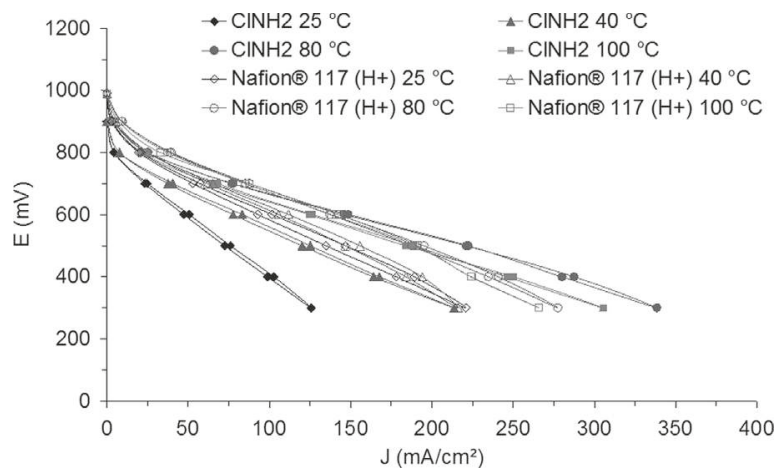

Fig. 11. Polarization curves of PEMFC PAXITECH at different temperatures, surfa$\mathrm{ce}=25 \mathrm{~cm}^{2}, \mathrm{H}_{2}$ and $\mathrm{O}_{2}$ flow rates $=120$ and $300 \mathrm{~cm}^{3} / \mathrm{min}, \mathrm{P}_{\mathrm{H}_{2}}=\mathrm{P}_{\mathrm{O}_{2}}=1$ bar.

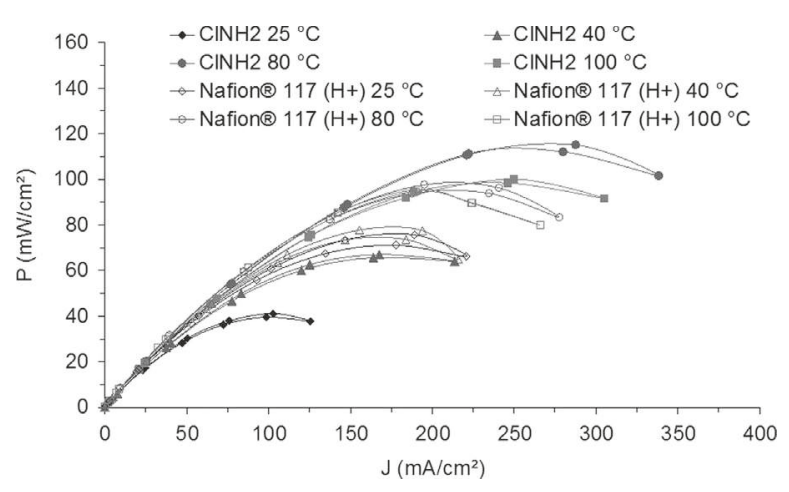

Fig. 12. Power density curves of PEMFC PAXITECH at different temperatures, surface $=25 \mathrm{~cm}^{2}, \mathrm{H}_{2}$ and $\mathrm{O}_{2}$ flow rates $=120$ and $300 \mathrm{~cm}^{3} / \mathrm{min}, \mathrm{P}_{\mathrm{H}_{2}}=\mathrm{P}_{\mathrm{O}_{2}}=1$ bar.

A durability test with gas humidification over a longer time period was performed for the $\mathrm{ClNH}_{2}$ membrane. A commercial Paxitech cell $\left(25 \mathrm{~cm}^{2}\right)$ with MEA containing $\mathrm{ClNH}_{2}$ membrane was operated discontinuously at room temperature and atmospheric pressure for more than $1000 \mathrm{~h}$. Ionic contact between electrodes and membrane was provided by drops of silica gel impregnated with an aqueous solution of sulfuric acid $(1 \mathrm{M})$. The flow rate of hydrogen and oxygen was respectively $50 \mathrm{~mL} / \mathrm{min}$ and $100 \mathrm{~mL} / \mathrm{min}$. The fuel cell was put into service every morning for $9 \mathrm{~h}$ of non-stop operation, and stopped in the evening on working-days. The fuel cell was connected to a resistance of $420 \mathrm{~m} \Omega$, made from $40 \mu \mathrm{m}$ diameter and $120 \mathrm{~cm}$ length of stainless steel wire. Fuel cell instantaneously started as soon as hydrogen gas was introduced. Its flow was stabilized within $10 \mathrm{~min}$ to $1.7 \mathrm{~A}( \pm 0.1 \mathrm{~A})$ at $0.6 \mathrm{~V}$ (about $1 \mathrm{~W}$ ). The working temperature of the cell stabilized in the vicinity of $35^{\circ} \mathrm{C}$. This long term test showed fairly good durability and the resistance to ageing and to repeated interruptions of the membranes.

Clearly, the membrane electrode assembly (MEA) has currently not been optimized. Besides, many parameters have to be studied such as membrane thickness, cross-linking rate, etc. In particular, it is expected that the properties and performances of the membranes can be further improved by control of the crosslinking rate. Moreover, further work is on the way to expand application domains of the membranes, like electrodialysis for example.

\section{Conclusion}

An easy crosslinking method of chlorosulfonated polyethersulfone $\left(\mathrm{SO}_{2} \mathrm{Cl}-\mathrm{PES}\right)$ with polyaminated crosslinking reagents for proton conducting membranes has been proposed. Two nonfluorinated crosslinked membranes have been prepared, characterized and tested in fuel cells.
Compared with sulfonated polyethersulfone membranes, the crosslinked membranes exhibit improved mechanical properties (ductile vs. brittle behavior) and show a decreased hydrophilic character. In particular, chemical crosslinking prevents the membrane from dissolution in water. TGA curves show a good stability of the membranes in the temperature range of PEMFC application. We have thus obtained membranes with increased chemical and thermal stability, improved mechanical properties and reduced swelling without considerably decreasing proton conductivity, comparable with that of Nafion ${ }^{\circledR}$.

The fuel cell performances with MEA containing those membranes are considered to have very promising results. The best results have been obtained with the $\mathrm{ClNH}_{2}$ membrane, crosslinked with amino-polyethersulfone and exhibiting electrochemical performances very similar to the Nafion ${ }^{\circledR}$ membrane in laboratory cells. A study investigating the suitability of the crosslinked membranes for application in electrodialysis is in process.

\section{Acknowledgments}

The authors thank the French ANRT (Agence Nationale pour la Recherche et la Technologie) for financial support, Prof. J. Roziere (Institut Charles Gerhard, Université Montpellier II, 34095 Montpellier Cedex 5, France) for measurements of proton conductivity at different temperatures and LEPMI (Laboratoire d'Electrochimie et de Physico Chimie des Matériaux et des Interfaces, St Martin d'Hères, F38402 Grenoble, France) for interesting discussions.

\section{References}

[1] M. Doyle, G. Rajendran, Perfluorinated Membranes, Handbook of Fuel Cells: Fundamentals, Technology and Applications, in: W. Vielstich, H.A. Gasteiger, A. Lamm (Eds.), Fuel Cell Technology and Applications, vol. 3, John Wiley \& Sons, Ltd., 2003.

[2] A. Ghielmi, P. Vaccarono, C. Troglia, V. Arcella, Proton exchange membranes based on the short-side-chain perfluorinated ionomer, J. Power Sources 145 (2005) 108-115.

[3] H.S. Byun, R.P. Burford, A.G. Fane, Sulfonation of cross-linked asymmetric membranes based on polystyrene and divinylbenzene, J. Appl. Polym. Sci. 52 (1994) 825-835.

[4] K.D. Kreuer, Hydrocarbon Membranes, Handbook of Fuel Cells-Fundamentals Technology and Applications, vol. 3-Fuel Cell Technology and Applications, 2003; 420-435.

[5] C.H. Park, C.H. Lee, M.D. Guiver, Y.M. Lee, Sulfonated hydrocarbon membranes for medium-temperature and low-humidity proton exchange membrane fuel cells (PEMFCs), Prog. Polym. Sci. 36 (2011) 1443-1498.

[6] D.J. Jones, J. Rozière, Recent advances in the functionalisation of polybenzimidazole and polyetherketone for fuel cell applications, J. Membr. Sci. 185 (2001) 41-58.

[7] K.D. Kreuer, On the development of proton conducting polymer membranes for hydrogen and methanol fuel cells, J. Membr. Sci. 185 (2001) 29-39.

[8] P. Xing, G.P. Robertson, M.D. Guiver, S.D. Mikhailenko, S. Kaliaguine, Synthesis and characterization of poly (aryl ether ketone) copolymers containing (hexafluoroisopropylidene)-diphenol moiety as proton exchange membrane materials, Polymer 46 (2005) 3257-3263.

[9] P. Xing, G.P. Robertson, M.D. Guiver, S.D. Mikhailenko, K. Wang, S. Kaliaguine, Synthesis and characterization of sulfonated poly (ether ether ketone) for proton exchange membranes, J. Membr. Sci. 229 (2004) 95-106.

[10] C. Zhao, X. Li, Z. Wang, Z. Dou, S. Zhong, H. Na, Synthesis of the block sulfonated poly (ether ether ketone)s (S-PEEKs) materials for proton exchange membrane, J. Membr. Sci. 280 (2006) 643-650.

[11] H. Dai, R. Guan, C. Li, J. Liu, Development and characterization of sulfonated poly (ether sulfone) for proton exchange membrane materials, Solid State Ionics 178 (2007) 339-345.

[12] P. Genova-Dimitrova, B. Baradie, D. Foscallo, C. Poinsignon, J.Y. Sanchez, Ionomeric membranes for proton exchange membrane fuel cell (PEMFC): sulfonated polysulfone associated with phosphatoantimonic acid, J. Membr. Sci. 185 (2001) 59-71.

[13] C. Iojoiu, P. Genova-Dimitrova, M. Maréchal, J.Y. Sanchez, Chemical and physicochemical characterizations of ionomers, Electrochim. Acta 51 (2006) 4789-4801.

[14] H.J. Kim, N.N. Krishnan, S.Y. Lee, S.Y. Hwang, D. Kim, K.J. Jeong, J.K. Lee, E. A. Cho, J. Lee, J. Han, Sulfonated poly (ether sulfone) for universal polymer electrolyte fuel cell operations, J. Power Sources 160 (2006) 353-358. 
[15] Y.S. Kim, B. Einsla, M. Sankir, W. Harrison, B.S. Pivovar, Structure-propertyperformance relationships of sulfonated poly (arylene ether sulfone) s as a polymer electrolyte for fuel cell applications, Polymer 47 (2006) 4026-4035.

[16] K. Matsumoto, T. Higashihara, M. Ueda, Locally and densely sulfonated poly (ether sulfone)s as proton exchange membrane, Macromolecules 42 (2009) 1161-1166.

[17] R. Nolte, K. Ledjeff, M. Bauer, R. Mülhaupt, Partially sulfonated poly (arylene ether sulfone)-a versatile proton conducting membrane material for modern energy conversion technologies, J. Membr. Sci. 83 (1993) 211-220.

[18] D. Poppe, H. Frey, K.D. Kreuer, A. Heinzel, R. Mülhaupt, Carboxylated and sulfonated poly (arylene-co-arylene sulfone)s: thermostable polyelectrolytes for fuel cell applications, Macromolecules 35 (2002) 7936-7941.

[19] E.E. Unveren, T. Erdogan, S.S. Çelebi, T.Y. Inan, Role of post-sulfonation of poly (ether ether sulfone) in proton conductivity and chemical stability of its proton exchange membranes for fuel cell, Int. J. Hydrogen Energy 35 (2010) 3736-3744.

[20] F. Wang, M. Hickner, Y.S. Kim, T.A. Zawodzinski, J.E. McGrath, Direct polymerization of sulfonated poly (arylene ether sulfone) random (statistical) copolymers: candidates for new proton exchange membranes, J. Membr. Sci. 197 (2002) 231-242.

[21] W. Mabrouk, L. Ogier, F. Matoussi, C. Sollogoub, S. Vidal, M. Dachraoui, J.F. Fauvarque, Preparation of new proton exchange membranes using sulfonated poly (ether sulfone) modified by octylamine (SPESOS), Mater. Chem. Phys. 128 (2011) 456-463.

[22] W. Mabrouk, L. Ogier, S. Vidal, C. Sollogoub, F. Matoussi, M. Dachraoui, J. F. Fauvarque, Synthesis and characterization of polymer blends of sulfonated polyethersulfone and sulfonated polyethersulfone octylsulfonamide for PEMFC applications, Fuel Cells 12 (2012) 179-187.

[23] J. Kerres, W. Cui, M. Junginger, Development and characterization of crosslinked ionomer membranes based upon sulfinated and sulfonated PSU crosslinked PSU blend membranes by alkylation of sulfinate groups with dihalogenoalkanes, J. Membr. Sci. 139 (1998) 227-241.

[24] J. Kerres, W. Zhang, A. Ullrich, C.M. Tang, M. Hein, V. Gogel, T. Frey, L. Jörissen, Synthesis and characterization of polyaryl blend membranes having different composition, different covalent and/or ionical cross-linking density, and their application to DMFC, Desalination 147 (2002) 173-178.

[25] S. Feng, Y. Shang, X. Xie, Y. Wang, J. Xu, Synthesis and characterization of crosslinked sulfonated poly (arylene ether sulfone) membranes for DMFC applications, J. Membr. Sci. 335 (2009) 13-20.

[26] A.A.M. Furtado Filho, A.S. Gomes, Crosslinked sulfonated polysulfone-based polymer electrolyte membranes induced by gamma ray irradiation, Int. J. Polym. Mater. 59 (2010) 424-437.

[27] K. Yaguchi, K. Chen, N. Endo, M. Higa, K. Okamoto, Crosslinked membranes of sulfonated polyimides for polymer electrolyte fuel cell applications, J. Power Sources 195 (2010) 4676-4684.

[28] X. Zhang, Z. Hu, S. Zhang, S. Chen, J. Liu, L. Wang, Preparation and properties of crosslinked multiblock sulfonated poly (arylene ether sulfone) membranes for fuel cell applications, J. Appl. Polym. Sci. 121 (2011) 1707-1716.

[29] P. Chen, X. Chen, Z. An, K. Chen, K. Okamoto, Quinoxaline-based crosslinked membranes of sulfonated poly(arylene ether sulfone)s for fuel cell applications, Int. J. Hydrogen Energy 36 (2011) 12406-12416.

[30] Y. Chen, C.H. Lee, J.R. Rowlett, J.E. McGrath, Synthesis and characterization of multiblock semi-crystalline hydrophobic poly(ether ether ketone)-hydrophilic disulfonated poly(arylene ether sulfone) copolymers for proton exchange membranes, Polymer 53 (2012) 3143-3153.
[31] S.D. Mikhailenko, G.P. Robertson, M.D. Guiver, S. Kaliaguine, Properties of PEMs based on cross-linked sulfonated poly (ether ether ketone), J. Membr. Sci. 285 (2006) 306-316.

[32] S.D. Mikhailenko, K. Wang, S. Kaliaguine, P. Xing, G.P. Robertson, M.D. Guiver Proton conducting membranes based on cross-linked sulfonated poly(ether ether ketone) (SPEEK), J. Membr. Sci. 233 (2004) 93-99.

[33] P. Conningham, R.J. Roach, J.B. Rose, P.T. McGrail, Synthesis of poly (phenylene ether sulphone)s containing aminated chain units, Polymer 33 (1992 3951-3956.

[34] W.H. Daly, S. Lee, C. Rungaroonthaikul, Modification of Condensation Polymers: Challenges and Opportunities, in: ACS Symposium Series, Oxford University Press, Cary, NC, United States (1988) 1988; 4-23.

[35] M. Guiver, G. Robertson, S. Foley, Chemical modification of polysulfones II: an efficient method for introducing primary amine groups onto the aromatic chain, Macromolecules 28 (1995) 7612-7621.

[36] C.-K. Lin, J.-F. Kuo, C.-Y. Chen, Preparation of nitrated sulfonated poly(ether ether ketone) membranes for reducing methanol permeability in direct methanol fuel cell applications, J. Power Sources 187 (2009) 341-347.

[37] H.A. Naik, I.W. Parsons, P.T. McGrail, P.D. MacKenzie, Chemical modification of polyarylene ether/sulphone polymers: preparation and properties of materials aminated on the main chain, Polymer 32 (1991) 140-145.

[38] D.-W. Seo, Y.-D. Lim, S.-H. Lee, Y.-G. Jeong, T.-W. Hong, W.-G. Kim, Preparation and characterization of sulfonated amine-poly(ether sulfone)s for proton exchange membrane fuel cell, Int. J. Hydrogen Energy 35 (2010) 13088-13095.

[39] J. Kerres, A. Ullrich, F. Meier, T. Häring Synthesis and characterization of nove acid-base polymer blends for application in membrane fuel cells, Solid State Ionics 125 (1999) 243-249.

[40] W. Zhang, C.M. Tang, J. Kerres, Development and characterization of sulfonated-unmodiftied and sulfonated-aminated PSU Udel ${ }^{\mathbb{R}}$ blend membranes, Sep. Purif. Technol. 22-23 (2001) 209-221.

41] L.-C. Chen, T.L. Yu, H.-L. Lin, S.-H. Yeh, Nafion/PTFE and zirconium phosphate modified Nafion/PTFE composite membranes for direct methanol fuel cells, J. Membr. Sci. 307 (2008) 10-20.

42] A.C. Fernandes, E.A. Ticianelli, A performance and degradation study of Nafion 212 membrane for proton exchange membrane fuel cells, J. Power Sources 193 (2009) 547-554.

[43] E. Agel, J. Bouet, J.F. Fauvarque, Characterization and use of anionic membranes for alkaline fuel cells, J. Power Sources 101 (2001) 267-274.

[44] C. Sollogoub, A. Guinault, C. Bonnebat, M. Bennjima, L. Akrour, J.F. Fauvarque, L. Ogier, Formation and characterization of crosslinked membranes for alkaline fuel cells, J. Membr. Sci. 335 (2009) 37-42.

[45] V.I. Zabolotsky, V.V. Nikonenko, N.D. Pismenskaya, On the role of gravitational convection in the transfer enhancement of salt ions in the course of dilute solution electrodialysis, J. Membr. Sci. 119 (1996) 171-181.

[46] V.I. Zabolotsky, V.V. Nikonenko, Effect of structural membrane inhomogeneity on transport properties, J. Membr. Sci. 79 (1993) 181-198.

[47] M. Taky, G. Pourcelly, F. Lebon, C. Gavach, Polarization phenomena at the interfaces between an electrolyte solution and an ion exchange membrane. Part I. Ion transfer with a cation exchange membrane, J. Electroanal. Chem. 336 (1992) 171-194.

[48] E. Sengül, H. Erdener, R.G. Akay, H. Yücel, N. Bac, I. Eroglu, Effects of sulfonated polyether-etherketone (SPEEK) and composite membranes on the proton exchange membrane fuel cell (PEMFC) performance, Int. J. Hydrogen Energy 34 (2009) 4645-4652. 